\title{
Effect of chronic hypoxia on calcium signalling in airway smooth muscle cells
}

\author{
N-E. Belouchi, E. Roux, J-P. Savineau, R. Marthan
}

\begin{abstract}
Effect of chronic hypoxia on calcium signalling in airway smooth muscle cells. N-E. Belouchi, E. Roux, J-P. Savineau, R. Marthan. ERS Journals Ltd 1999.

ABSTRACT: Chronic hypoxia $(\mathrm{CH})$ alters smooth muscle contractility. $\mathrm{CH}$ generally produces a sustained attenuation of vasoreactivity. In airways, this effect of $\mathrm{CH}$ is poorly understood although $\mathrm{CH}$ is frequently observed in patients with pulmonary diseases.

This study was designed to examine the effect of $\mathrm{CH}$ on both the isometric contraction of isolated rings and the cytosolic calcium concentration $\left(\left[\mathrm{Ca}^{2+}\right] \mathrm{i}\right)$ using microspectrofluorimetry in freshly isolated cells from rat tracheal smooth muscle. Tissues were obtained from both chronically hypoxic rats maintained in a hypobaric chamber $(50.5 \mathrm{kPa})$ for 15 days and normoxic animals.

CH increased the sensitivity of airway smooth muscle to cholinergic agonists. This increase observed in the mechanical activity (concentration of carbachol producing $50 \%$ of the maximal force (EC50) in tissues from normoxic and hypoxic animals: 0.80 $\mu \mathrm{M}(0.39-1.21 \mu \mathrm{M})$ and $0.34 \mu \mathrm{M}(0.08-0.59 \mu \mathrm{M})$, respectively, $\mathbf{p}<0.05)$ was related to an increase in the sensitivity of cholinergic-mediated $\mathrm{Ca}^{2+}$ release (acetylcholine EC50 in cells from normoxic and hypoxic animals: $0.14 \mu \mathrm{M}(0.11-0.17 \mu \mathrm{M})$ and $0.04 \mu \mathrm{M}$ $(0.026-0.054 \mu \mathrm{M})$, respectively, $\mathbf{p}<0.05)$.

It was concluded that chronic hypoxia alters calcium signalling in airway smooth muscle cells, which was associated with an increase in airway responsiveness in vitro. Whether a similar phenomenon contributes to bronchial hyperresponsiveness in chronically hypoxaemic patients remains to be established. Eur Respir J 1999; 14: 74-79.
\end{abstract}

\begin{abstract}
Laboratoire de Physiologie Cellulaire Respiratoire, INSERM (E 9937), Université Victor Segalen Bordeaux, Bordeaux,
\end{abstract} France.

Correspondence: R. Marthan, Laboratoire de Physiologie Cellulaire Respiratoire, INSERM (E 9937), Université Victor Segalen Bordeaux 2, 146 rue Léo Saignat, 33076 Bordeaux Cedex, France. Fax: 33 557571501

Keywords: Acetylcholine, calcium oscillations, chronic hypoxia, excitation-contraction coupling, indo-1, smooth muscle

Received: September 251998

Accepted after revision January 151999

This study was supported by grants from Ministère de $1^{\prime}$ Environnement-ADEMEINERIS (No. 97034), Conseil Regional d'Aquitaine (No. 960301117) and Institut National de la Santé et de la Recherche Médicale (CRI 9806).
Both acute and chronic hypoxia alter smooth muscle contractility [1-3]. In airways, acute hypoxia appears to increase responsiveness both in vitro [4] and in vivo [59]. Surprisingly, the effect of chronic hypoxia on airway smooth muscle is poorly understood, although chronic hypoxia is frequently observed in patients with chronic obstructive pulmonary disease [10] and may play a role in the bronchial hyperresponsiveness associated with this disease [11].

Chronic hypoxia has profound effects on smooth muscle contractility in vascular beds. It produces a sustained attenuation of uterine, cerebral, pulmonary and systemic vasoreactivity in response to a variety of agonists such as serotonin, noradrenalin or angiotensin II [2, 12-15]. Yet the cellular mechanisms underlying chronic hypoxiamediated smooth muscle responses are not well understood [16]. It has been suggested that hypoxia decreases force in phasic smooth muscle as a result of impaired electromechanical coupling (i.e. coupling which is dependent on changes in the membrane potential of the smooth muscle cell) [3]. In tonic smooth muscle such as vessels (as well as airways), chronic hypoxia alters smooth muscle pharmacomechanical coupling (i.e. coupling that is independent of changes in the membrane potential of the smooth muscle cell) by modifying the function of cell membrane receptors and the downstream signalling coupl- ed to these receptors, in particular, intracellular calcium release [13]. Additionally or alternatively, chronic hypoxia may also act on cells other than myocytes, for example endothelial cells.

The free intracellular calcium concentration $\left(\left[\mathrm{Ca}^{2+}\right] \mathrm{i}\right)$ plays a critical role in determining the contraction of airway smooth muscle [17]. Calcium signalling in response to agonist can now be more precisely investigated in isolated airway smooth muscle cells by microspectrofluorimetric techniques using fluorescent dyes. This technique has revealed that agonists induce the $\left[\mathrm{Ca}^{2+}\right] \mathrm{i}$ oscillations, initially described in nonexcitable cells, in airway smooth muscle cells $[18,19]$. These $\left[\mathrm{Ca}^{2+}\right] \mathrm{i}$ oscillations arise from the cyclic release and re-uptake of $\mathrm{Ca}^{2+}$ in intracellular stores.

To the authors' knowledge, no study has yet been performed to examine the effect of chronic hypoxia on the mechanical activity and $\mathrm{Ca}^{2+}$ homeostasis of airway smooth muscle. The present work was thus designed to compare muscarinic-induced $\left[\mathrm{Ca}^{2+}\right]$ i oscillations in airway smooth muscle cells obtained from chronically hypoxic rats maintained in a hypobaric chamber $(50.5 \mathrm{kPa})$ for 15 days with those in control cells obtained from normoxic animals, in order to understand the mechanism of chronic hypoxia-induced changes in airway mechanical activity. 


\section{Methods}

\section{Chronic hypoxia}

Male Wistar rats, 10-12 weeks old, weighing 250-300 g were exposed to chronic hypoxia as follows. They were exposed to a simulated altitude of $5000 \mathrm{~m}$ (barometric pressure $50.5 \mathrm{kPa}$ ) in a well-ventilated temperature controlled hypobaric chamber for 15 days. Free access to a standard rat diet and water was allowed throughout the exposure period. The chamber was opened twice a week for a few minutes to clean the cages and to remove and replace the animal that had completed a 2-week stay in the chamber. By doing this, experiments were performed on a regular basis, immediately after the chronic hypoxia exposure to limit the time spent in normoxia. Normoxic rats were kept in the same room with the same light/dark cycle. Rat food and water were provided ad libitum.

\section{Tissue preparation}

For each experiment, a rat was anaesthetized by intraperitoneal administration of $400 \mathrm{mg}$ ethylcarbamate. The heart and lungs were removed en bloc in a normoxic physiological medium (i.e. equilibrated with air), and the trachea was rapidly dissected out. The heart was also quickly removed, dissected and weighed. The ratio of right ventricular free wall weight to the sum of septum plus left ventricular free wall weight (fresh tissue) was used as an index of right ventricular hypertrophy resulting from chronic hypoxia-induced pulmonary hypertension.

For isometric contraction measurements, the trachea was cut into 4 rings of similar 3-mm diameter and 3-4 $\mathrm{mm}$ in length as previously described [20].

For fluorescence measurements of $\left[\mathrm{Ca}^{2+}\right] \mathrm{i}$ in freshly isolated cells, the muscular strip located on the dorsal face of the trachea was further dissected for approximately $1 \mathrm{~h}$ in a normoxic physiological medium under a binocular control as previously described [18]. Briefly, the epithelium was removed and the epithelium-free muscular strip was cut into several pieces (1 $1 \mathrm{~mm})$ and incubated for $10 \mathrm{~min}$ in low-Ca ${ }^{2+}(200 \mu \mathrm{M})$ physiological saline solution (PSS, composition given below). Tissue was then incubated in low- $\mathrm{Ca}^{2+}$ PSS containing $1.0 \mathrm{mg} \cdot \mathrm{mL}^{-1}$ collagenase, $0.7 \mathrm{mg} \cdot \mathrm{mL}^{-1}$ pronase, $0.06 \mathrm{mg} \cdot \mathrm{mL}^{-1}$ elastase and $3 \mathrm{mg} \cdot \mathrm{mL}^{-1}$ bovine serum albumin at $37^{\circ} \mathrm{C}$ for two successive periods of $25 \mathrm{~min}$. After this time, the solution was removed and the tracheal muscle pieces were incubated again in a fresh enzyme-free solution and triturated with a fire-polished Pasteur pipette to release cells. Cells were allowed to attach to glass cover slips at $4{ }^{\circ} \mathrm{C}$ in PSS containing $0.8 \mathrm{mM} \mathrm{Ca}^{2+}$ and used on the same day.

\section{Isometric contraction measurement}

Isometric contraction was measured in airway smooth muscle rings mounted between two stainless steel clips in the vertical $20-\mathrm{mL}$ organ baths of a computerized isolated organ bath system (IOS1; EMKA Technologies, Paris, France) as described previously [20]. Baths were filled with Krebs-Henseleit solution (composition in mM: 118.4 $\mathrm{NaCl}, 4.7 \mathrm{KCl}, 2.5 \mathrm{CaCl}_{2} \cdot 2 \mathrm{H}_{2} \mathrm{O}, 1.2 \mathrm{MgSO}_{4} \cdot 7 \mathrm{H}_{2} \mathrm{O}, 1.2$ $\mathrm{KH}_{2} \mathrm{PO}_{4}, 25.0 \mathrm{NaHCO}_{3}, 11.1$ D-glucose, $\mathrm{pH}$ 7.4) main- tained at $37^{\circ} \mathrm{C}$ and bubbled with a $95 \% \mathrm{O}_{2} / 5 \% \mathrm{CO}_{2}$ gas mixture. The upper stainless steel clip was connected to an isometric force transducer (ENWA Technologies). Tissues were set at optimal length by equilibration against a passive load of $1.5 \mathrm{~g}$, as previously determined for this type of preparation [20]. At the beginning of each experiment, a supramaximal stimulation with acetylcholine (ACh, $10^{-3}$ $M$ final concentration in the bath) was administered to each of the rings to elicit a reference response that was used to assess the viability of the tissue. After washing the rings with fresh Krebs-Henseleit solution to eliminate the ACh response, a cumulative concentration/response curve (CCRC) to carbachol was constructed. Carbachol was used as a convenient cholinergic agonist since, unlike $\mathrm{ACh}$, it is not metabolized by acetylcholinesterase and thus can be used to construct steady-state CCRCs. At the end of the experiment, which lasted $\sim 3 \mathrm{~h}$ during which rings were exposed to hyperoxia, tissues were blotted slightly and weighed (wet weight).

\section{Fluorescence measurement and estimation of $\left[\mathrm{Ca}^{2+}\right]_{i}$}

Changes in $\left[\mathrm{Ca}^{2+}\right] \mathrm{i}$ were monitored fluorimetrically using the $\mathrm{Ca}^{2+}$-sensitive dye probe indo- 1 as described previously $[18,21]$. Freshly isolated cells were loaded with indo- 1 by incubation in normoxic PSS containing 1 $\mu \mathrm{M}$ indo-1 pentaacetoxymethyl ester (indo-1 AM) for 25 min at room temperature and then washed in PSS for 25 min. Coverslips with attached cells were then mounted in a perfusion chamber and continuously superfused with a normal external calcium containing solution at room temperature (see composition below). The recording system included a Nikon Diaphot inverted microscope fitted with epifluorescence (Nikon France, Charenton-lepont, France). A single cell was illuminated at a wavelength of $360 \pm 10 \mathrm{~nm}$. Emitted light from a window slightly larger than the cell was counted simultaneously at $405 \mathrm{~nm}$ and $480 \mathrm{~nm}$ by two photomultipliers (P100, Nikon). Voltage signals at each wavelength were stored in an IBM personal computer for subsequent analysis. The fluorescence ratio (405/480) was calculated online and displayed with the two voltage signals on a monitor. $\left[\mathrm{Ca}^{2+}\right] \mathrm{i}$ was estimated from the $405 / 480$ ratio using a calibration for indo-1 determined within cells [22].

PSS contained (in mM): $130 \mathrm{NaCl}, 5.6 \mathrm{KCl}, 1 \mathrm{MgCl}_{2}, 2$ $\mathrm{CaCl}_{2}, 11$ D-glucose, 10 HEPES, pH 7.4 with $\mathrm{NaOH}$ and was equilibrated with air. ACh was applied to the test cell by a 30 -s pressure ejection from a glass pipette located close to the cell. No changes in $\left[\mathrm{Ca}^{2+}\right]$ i were observed during test ejections of PSS (data not shown). Generally, each record of $\left[\mathrm{Ca}^{2+}\right]$ i response to ACh was obtained from a different cell. Each type of experiment was repeated for the number of cells indicated in the text, was conducted in cells isolated from one trachea, and took 3-4 h.

\section{Chemicals and drugs}

Collagenase (type CLS1) was from Worthington Biochemical Corporation (Freehold, NJ, USA). Pronase (type E), elastase (type 3), bovine serum albumin, ACh and carbachol were purchased from Sigma (Saint Quentin Fallavier, France). Indo-1 AM was from Calbiochem (France Biochem, Meudon, France). 
Indo-1 AM was dissolved in dimethylsulphoxide (DM$\mathrm{SO})$. The maximal concentration of DMSO used in the experiments was $<0.1 \%$ and had no effect on the resting value of the $\left[\mathrm{Ca}^{2+}\right]$ i nor on the variation the $\left[\mathrm{Ca}^{2+}\right]$ i induced by ACh (data not shown).

\section{Statistical and data analysis}

Since the expression of the force developed by airway smooth muscle requires normalization to properly assess the effect of chronic hypoxia, the mechanical response in each ring to each concentration of carbachol was expressed as a percentage of both raw force value normalized to wet weight and percentage of the maximal contractile response to carbachol in the ring at completion of the CCRC. Since in each experiment (i.e. each rat trachea) duplicate rings were studied, a mean CCRC was calculated to be representative of that airway specimen. Overall mean CCRCs were calculated for all experiments in both control and chronically hypoxic animals. Mechanical responses are given as mean \pm SEM. CCRCs expressed using raw force value normalized to wet weight were compared using a two-way analysis of variance (ANOVA).

CCRCs expressed using percentage of the maximal contractile response to carbachol were fitted by a nonlinear regression equation: $F / F \max =C /[(\mathrm{EC} 50)+C]$ where $F$ is the force, $F \max$ the maximal force, $C$ the concentration and EC50 the concentration producing $50 \%$ of the maximal force. Differences in EC50 values were tested using the nonlinear regression analysis described by MeDDINGs et al. [23].

Results of $\left[\mathrm{Ca}^{2+}\right] \mathrm{i}$ are expressed as the mean \pm SEM. Significance was tested by means of the Student's t-test. When concentration/response curves were constructed, the mean $\left[\mathrm{Ca}^{2+}\right]$ i values calculated for the various concentrations of agonist were fitted by the logistic equation: I/Imax $=C^{\mathrm{h}}\left[(\mathrm{EC} 50)^{\mathrm{h}}+C^{\mathrm{h}}\right]$ where $\mathrm{I}$ is the $\left[\mathrm{Ca}^{2+}\right] \mathrm{i}$ increase, Imax the maximal $\left[\mathrm{Ca}^{2+}\right]$ i increase, $C$ the concentration of agonist, $\mathrm{h}$ a factor related to the slope of the sigmoidal curve, and EC50 the concentration producing $50 \%$ of the maximal increase [24]. Differences in EC50 or Imax were tested by nonlinear regression analysis. Results were considered significant at $\mathrm{p}<0.05$.

\section{Results}

Effect of chronic hypoxia on carbachol-induced isometric contraction in isolated tracheal smooth muscle rings

There was a consistent increase in the ratio of right ventricular free wall to the sum of septum plus left ventricular free wall weight in rats exposed to chronic hypoxia $(47 \pm 0.8 \%)$ when compared to controls $(27 \pm 1 \%, \mathrm{n}=35, \mathrm{p}<$ 0.05 ) indicating the presence of right ventricular hypertrophy resulting from chronic hypoxia induced pulmonary hypertension.

Chronic hypoxia did not modify the raw maximal force (i.e. the reactivity) of rat tracheal smooth muscle in response to carbachol $(448 \pm 106$ and $475 \pm 60 \mathrm{mg} \cdot \mathrm{mg}$ wet weight $^{-1}$ in tissues from hypoxic and normoxic animals, respectively, $n=8$, Ns) (fig. 1a). However, it appeared to increase the sensitivity significantly and this effect was better analysed when the CCRCs were normalized to the
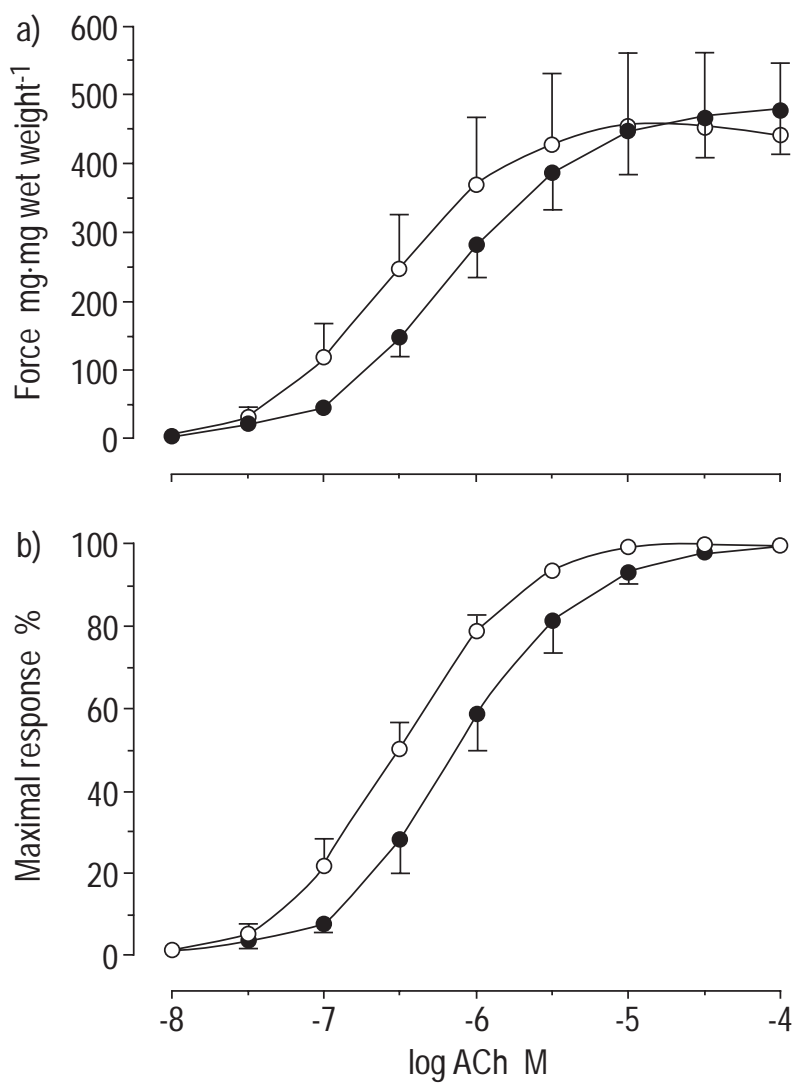

Fig. 1. - Mean cumulative concentration/response curves for carbachol in isolated tracheal rings from normoxic $(\bullet)$ and chronically hypoxic rats (O). a) Contractile response to each concentration of carbachol expressed as a raw value of force (mg) normalized to the wet weight of each tissue. b) Contractile response to each concentration of carbachol as a percentage of the maximal response in each tissue. Mean experimental points are fitted to a nonlinear regression equation. Vertical bar indicates SEM.

maximal contractile response and fitted by a nonlinear equation (fig. 1b). Calculated EC50 were then $0.80(95 \%$ confidence interval (CI) $0.39-1.21)$ and 0.34 (95\% CI $0.08-0.59) \mu \mathrm{M}$ in tissues from normoxic and hypoxic animals, respectively $(\mathrm{p}<0.05)$.

\section{Effect of chronic hypoxia on acetylcholine-induced $\left[\mathrm{Ca}^{2+}\right]$ i increase in isolated tracheal smooth muscle cells}

In tracheal smooth muscle cells from normoxic rats, the mean resting $\left[\mathrm{Ca}^{2+}\right] \mathrm{i}$ was $116 \pm 2.6 \mathrm{nM}(\mathrm{n}=190)$. At low concentrations, stimulation by $\mathrm{ACh}$ caused a rapid and graded increase in $\left[\mathrm{Ca}^{2+}\right] \mathrm{i}$, which gradually declined (fig. 2a). This first peak was followed, when the ACh concentration increased, in approximately half of the cells by successive peaks of decreasing amplitude $\left(\left[\mathrm{Ca}^{2+}\right] \mathrm{i}\right.$ oscillations) (fig. 2b). The amplitude of the first $\left[\mathrm{Ca}^{2+}\right]$ i peak and the frequency of the $\left[\mathrm{Ca}^{2+}\right]$ i oscillations depended on the ACh concentration (fig. 3).

Chronic hypoxia altered neither the resting $\left[\mathrm{Ca}^{2+}\right] \mathrm{i}$, which was $113 \pm 1.5 \mathrm{nM}(\mathrm{n}=276)$, nor the overall pattern of the calcium response, regardless of the ACh concentration (fig. 2b). However, it did shift the relationship between ACh concentrations and the amplitude of the first $\left[\mathrm{Ca}^{2+}\right] \mathrm{i}$ peak to the left, i.e. airway smooth muscle cells from 

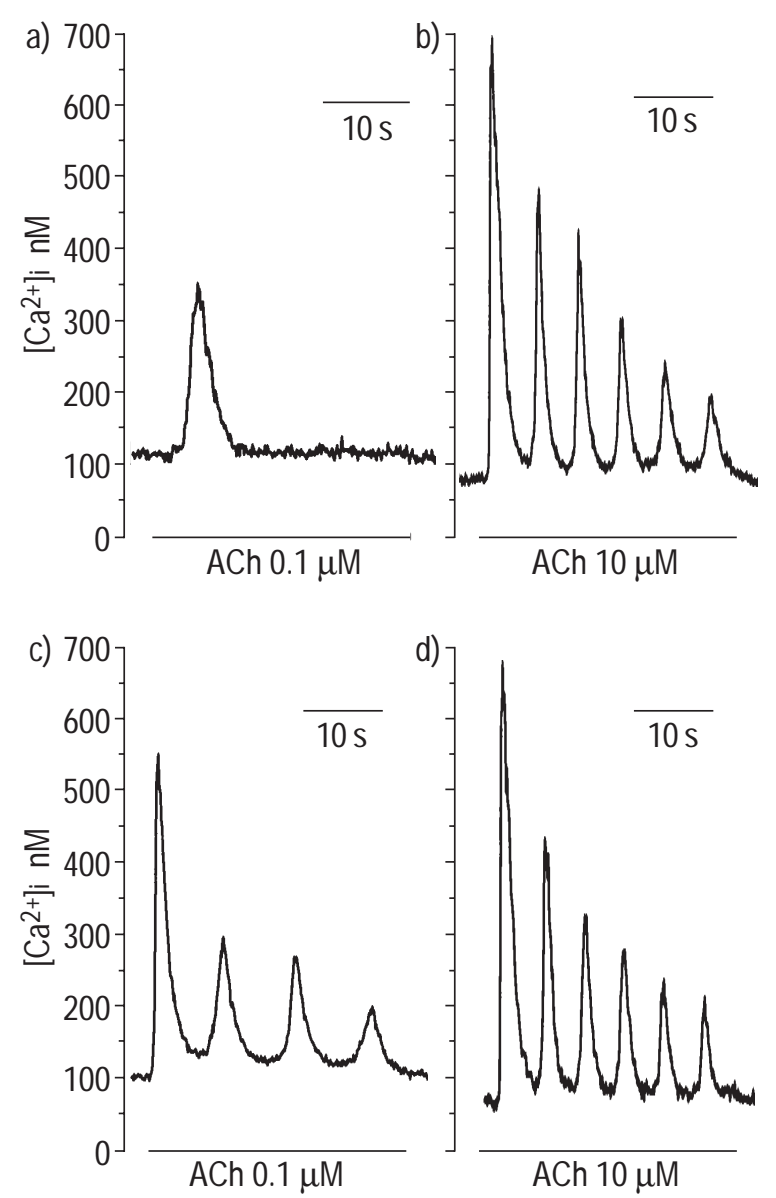

Fig. 2. - Effect of acetylcholine (ACh) on the free intracellular calcium concentration $\left(\left[\mathrm{Ca}^{2+}\right] \mathrm{i}\right)$ in freshly isolated rat tracheal smooth muscle cells loaded with indo-1. a, b) Control cells: a) low concentrations of $\mathrm{ACh}(30 \mathrm{~s}$, concentration indicated on the trace) induce a first graded $\left[\mathrm{Ca}^{2+}\right]$ i peak followed, for concentrations $>0.3 \mathrm{mM}$, by b) oscillations of decreasing amplitude. c, d) Cells from chronically hypoxic rats: c) low concentrations of ACh $(30 \mathrm{~s}$, concentration indicated on the trace) induce $\mathrm{Ca}^{2+}$ oscillations of low frequency; d) higher concentrations induce $\mathrm{Ca}^{2+}$ oscillations similar to those observed in control cells. Each trace is representative of 24-89 different cells.

chronically hypoxic rats were more sensitive to ACh than cells from control animals (fig. 3a). In cells from hypoxic animals, the EC50 $(0.04 \mu \mathrm{M} ; 95 \%$ CI $0.026-0.054 \mu \mathrm{M})$ was significantly lower than the EC50 calculated for cells from normoxic rats $(0.14 \mu \mathrm{M}, 95 \%$ CI $0.11-0.17 \mu \mathrm{M})$.

Chronic hypoxia did not alter the maximal oscillation frequency $(10.94 \pm 1.0(\mathrm{n}=21)$ versus $10.57 \pm 1.2(\mathrm{n}=17)$ oscillations $\mathrm{min}^{-1}$ in controls), but lowered the ACh concentration at which the maximal frequency was observed (fig. $3 b)$.

\section{Discussion}

The main finding of this study was that prolonged exposure to hypoxia increases the mechanical responsiveness of airway muscle rings to a cholinergic agonist and is a consequence of an effect on intracellular calcium release in smooth muscle cells. Chronic hypoxia increases the sensitivity of airways to carbachol (i.e. shifts the CCRC to the left) without altering the maximal contractile response. Similarly, chronic hypoxia shifts the relationship between
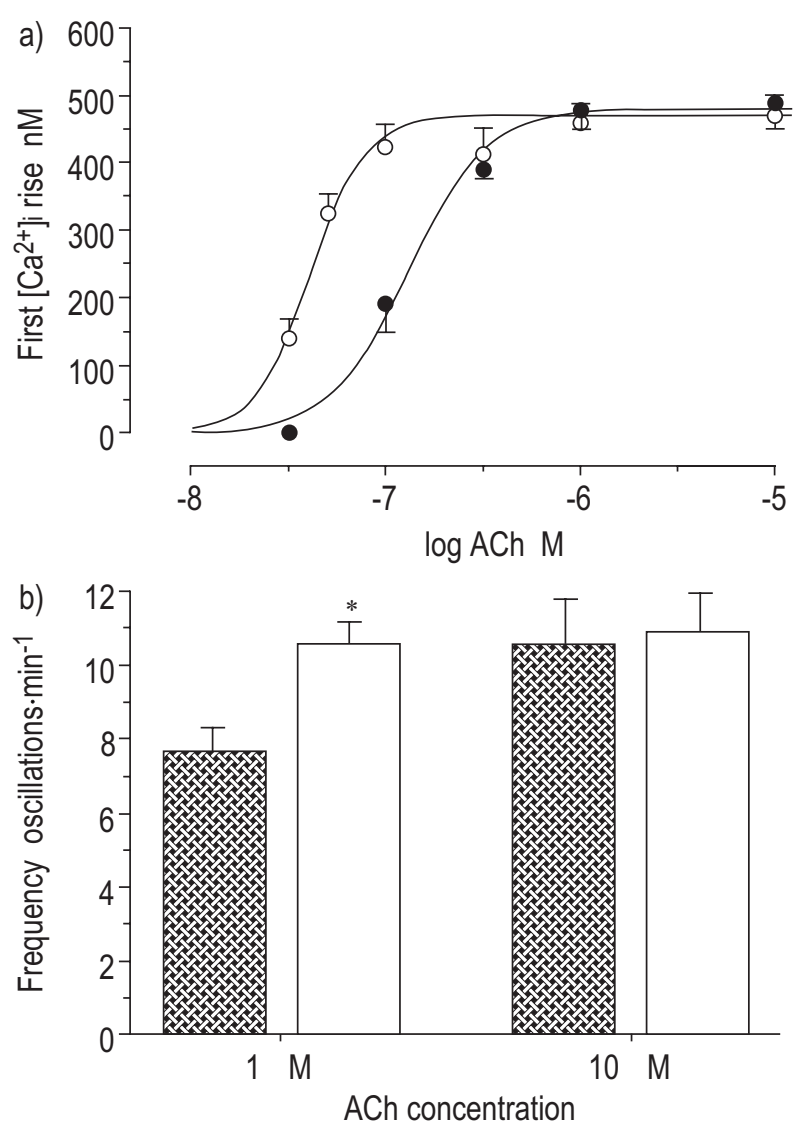

Fig. 3. - Concentration/response characteristics of the acetylcholine (ACh)-induced $\left[\mathrm{Ca}^{2+}\right] \mathrm{i}$ response in freshly isolated tracheal smooth muscle cells loaded with indo-1 from normoxic (, and chronically hypoxic rats $(\mathrm{O}, \square)$. a) The net amplitude of $\left[\mathrm{Ca}^{2+}\right]$ i rise (the maximal increase above resting baseline concentration) is plotted against acetylcholine (ACh) concentration; each symbol represents the mean value of $\left[\mathrm{Ca}^{2+}\right]$ i rise calculated for 24-89 cells; the vertical bar indicates SEM. Mean experimental points are fitted to a nonlinear regression equation. b) Relationship between two different ACh concentrations and the frequency of oscillations; each column represents the mean frequency value of oscillations calculated in $16-23$ cells generating $\left[\mathrm{Ca}^{2+}\right]$ i oscillations, the vertical bar indicates SEM. *: $\mathrm{p}<0.05$.

the concentration of cholinergic agonist and $\left[\mathrm{Ca}^{2+}\right]$ i to the left without altering the maximal $\left[\mathrm{Ca}^{2+}\right] \mathrm{i}$ value or the frequency of $\mathrm{Ca}^{2+}$ oscillations.

In the present study, the effects of exposure to chronic hypoxia were evaluated in rat tracheal smooth muscle. This mechanistic study was designed to dissociate the effect of hypoxia on airway smooth muscle from those on other cell types within the airway wall and to investigate the effect on calcium signalling. Hypoxia, as presented in this study, simulates a clinically and physiologically relevant condition.

Some studies have been devoted to examining the effect of chronic hypoxia on vascular reactivity in vessels. DOYLE and WALKER [12] reported that, in rats exposed to hypobaric hypoxia for 4 weeks, pressor responses to infused agonist administered in vivo were inhibited. This effect was not reversed on return to normoxia. The in vitro contractility of aortic segments from these rats was also depressed, indicating that chronic hypoxia caused a change in the vessel wall (smooth muscle or endothelium) independent of systemic reflexes. In the pulmonary circulation, 
in addition to the effect on arteries, chronic hypoxia impairs pulmonary venous smooth muscle contractility and reduces pulmonary venous reactivity and sensitivity to angiotensin II [2]. Recently, TOPORSIAN and WARD [15] demonstrated that the decrease in diaphragmatic arteriolar responsiveness following exposure to hypoxia was due to impaired smooth muscle contractility and not to the release of endothelium-derived factors. In the present study, it was observed that, unlike in the above vascular beds, chronic hypoxia increased airway responsiveness. In this respect, in airways, the effect of chronic hypoxia resembles that of acute hypoxia which also increases airway responsiveness both in vitro [4] and in vivo [5-9].

The mechanism of chronic hypoxia-induced vascular smooth muscle hyporeactivity has been examined in uterine arteries [25]. As in most tonic smooth muscle [3], chronic hypoxia does not affect the electromechanical coupling (i.e. coupling which is dependent on changes in the membrane potential of the smooth muscle cell related to the activation of voltage-dependent ion channels) but significantly suppresses pharmacomechanical coupling mediated by the activation of guanosine triphosphate-binding protein-coupled receptors in smooth muscle. Studies in rabbit systemic arteries have also indicated that receptor operated processes are sensitive to hypoxia [26]. Similarly, a recent study in conscious rats has confirmed that, unlike in acute hypoxia [1], opening of $\mathrm{K}^{+}$-adenosine triphosphate channels is not involved in the attenuated vasoreactivity associated with chronic hypoxia [16], further supporting the idea that the mechanism of action is independent of changes in membrane potential.

Muscarinic stimulation of isolated rat tracheal smooth muscle cells also activates the pharmacomechanical coupling, inducing $\left[\mathrm{Ca}^{2+}\right]$ i oscillations. The first component of the muscarinic-induced $\left[\mathrm{Ca}^{2+}\right]$ i signal is a transient and rapid rise in $\left[\mathrm{Ca}^{2+}\right] \mathrm{i}$, the amplitude of which depends upon the concentration of the muscarinic agonist $[18,19] . \mathrm{Ca}^{2+}$ is released from intracellular stores in a quantal manner with an increasing fraction of the store becoming involved in the overall $\left[\mathrm{Ca}^{2+}\right]$ i signal as the concentration of $\mathrm{ACh}$ and hence inositol-1,4,5-triphosphate $\left(\mathrm{IP}_{3}\right)$ increases. The second component of the muscarinic-induced $\left[\mathrm{Ca}^{2+}\right] \mathrm{i}$ signal is, in $\sim 50-60 \%$ of the cells, successive peaks of decreasing amplitude $\left(\left[\mathrm{Ca}^{2+}\right]\right.$ i oscillations $)$ also related to a repetitive $\mathrm{Ca}^{2+}$ release from intracellular $\mathrm{Ca}^{2+}$ stores $[18,19]$. This phenomenon is in agreement with the complex positive and negative feedback control of the $\mathrm{IP}_{3}$ receptor channel by $\mathrm{Ca}^{2+}[18,19]$. As could be derived from the studies investigating the mechanism of chronic hypoxia-induced vascular hyporesponsiveness, chronic hypoxia-induced airway hyperresponsiveness is related to its effect on airway smooth muscle pharmacomechanical coupling. Chronic hypoxia shifted the relationship between ACh concentration and the amplitude of the first $\left[\mathrm{Ca}^{2+}\right]$ i peak to the left but did not alter the maximal oscillation frequency, although it did lower the $\mathrm{ACh}$ concentration inducing this maximal frequency. This effect on calcium signalling can explain the effect on the mechanical activity. Since the frequency of oscillation plays a role in determining the maximal mechanical response $[18,19]$, the lack of an effect of chronic hypoxia on the maximal oscillation frequency accounts for the lack of an effect on the maximal contractile response to the cholinergic agonist. However, the effect of chronic hypoxia on the amplitude of the first $\left[\mathrm{Ca}^{2+}\right]$ i peak at low ACh concentrations, and on the threshold ACh concentrations required to produce oscillations or to maximally increase oscillation frequency, accounts for the increase in the sensitivity of airways to carbachol.

Precise determination of the molecular target of chronic hypoxia in airways requires complementary investigations. Depending on the vascular bed in question, either $\mathrm{IP}_{3}$ binding affinity to the $\mathrm{IP}_{3}$ receptor or the density of the receptor may be altered $[3,25,27]$. Also, despite the fact that the chronic hypoxia-induced effect on calcium signalling was a parallel of that on the mechanical activity, $\mathrm{Ca}^{2+}$ sensitivity of the contractile apparatus is also a key mechanism governing the contractility of smooth muscle [28]. Whether or not chronic hypoxia decreases the $\mathrm{Ca}^{2+}$ sensitivity of smooth muscle remains uncertain.

In conclusion, the present study provides evidence that mild chronic hypoxia alters calcium signalling in airway smooth muscle cells leading to an increase in airway responsiveness in vitro. As in vascular smooth muscle, the target of chronic hypoxia in airway smooth muscle appears to be the pharmacomechanical coupling, although in the former case chronic hypoxia impairs the pharmacomechanical coupling leading to a decrease in vascular responsiveness. Whether a similar phenomenon contributes to bronchial hyperresponsiveness in chronically hypoxaemic patients remains to be established.

Acknowledgements. The authors thank $\mathrm{H}$ Crevel for technical assistance.

\section{References}

1. Savineau JP, Gonzalez de la Fuente P, Marthan R. Cellular mechanisms of hypoxia-induced contraction in human and rat pulmonary arteries. Respir Physiol 1995; 99: 191198.

2. Zhao Y, Packer CS, Rhoades RA. Chronic hypoxia impairs pulmonary venous smooth muscle contraction. Respir Physiol 1995; 100: 75-82.

3. Taggart MJ, Wray S. Hypoxia and smooth muscle function: key regulatory events during metabolic stress. J Physiol (Lond) 1998; 509: 315-325.

4. Clayton RA, Nally JE, Thomson NC, McGrath JC. Changing the oxygen tension alters the ability of bronchodilators to protect against methacholine-induced challenge in bovine isolated bronchial rings. Pulm Pharmacol Ther 1997; 10: 51-60.

5. D'Brot J, Ahmed T. Hypoxia-induced enhancement of nonspecific bronchial reactivity: role of leukotrienes. $J$ Appl Physiol 1988; 65: 194-199.

6. D'Brot J, Ahmed T. Hyperoxia prevents hypoxia-induced bronchial hyperreactivity via a cyclooxygenase-independent mechanism. J Appl Physiol 1991; 70: 740-747.

7. Ahmed T, Marchette B. Hypoxia enhances nonspecific bronchial reactivity. Am Rev Respir Dis 1985; 132: 839844.

8. Denjean A, Roux C, Herve P, et al. Mild isocapnic hypoxia enhances the bronchial response to methacholine in asthmatic subjects. Am Rev Respir Dis 1988; 138: 789 793.

9. Dagg KD, Thomson LJ, Clayton RA, Ramsay SG, Thomson NC. Effect of acute alterations in inspired oxygen tension on methacholine induced bronchoconstriction in patients with asthma. Thorax 1997; 52: 453-457. 
10. Marthan R, Castaing Y, Manier G, Guenard H. Gas exchange alterations in patients with chronic obstructive lung disease. Chest 1985; 87: 470-475.

11. Yan K, Salome CM, Woolcock AJ. Prevalence and nature of bronchial hyperresponsiveness in subjects with chronic obstructive pulmonary disease. Am Rev Respir Dis 1985; 132: 25-29.

12. Doyle MP, Walker BR. Attenuation of systemic vasoreactivity in chronically hypoxic rats. Am J Physiol 1991; 260: R1114-R1122.

13. Hu XQ, Zhang L. Chronic hypoxia suppresses pharmacomechanical coupling of the uterine artery in near-term pregnant sheep. J Physiol (Lond) 1997; 499: 551-559.

14. Auer G, Ward ME. Impaired reactivity of rat aorta to phenylephrine and $\mathrm{KCl}$ after prolonged hypoxia: role of the endothelium. J Appl Physiol 1998; 85: 411-417.

15. Toporsian M, Ward ME. Hyporeactivity of rat diaphragmatic arterioles after exposure to hypoxia in vivo. Role of the endothelium. Am J Respir Crit Care Med 1997; 156: 1572-1578.

16. Eichinger MR, Resta TC, Balderrama DS, et al. Glibenclamide does not reverse attenuated vasoreactivity to acute or chronic hypoxia. J Appl Physiol 1995; 79: 1173-1180.

17. Savineau JP, Marthan R. Activation properties of chemically skinned fibres from human isolated bronchial smooth muscle. J Physiol 1994; 474: 433-438.

18. Roux E, Guibert C, Savineau JP, Marthan R. [Ca2+]i oscillations induced by muscarinic stimulation in airway smooth muscle cells: receptor subtypes and correlation with the mechanical activity. Br J Pharmacol 1997; 120: 1294-1301.

19. Roux E, Molimard M, Savineau JP, Marthan R. Muscarinic stimulation of airway smooth muscle cells. Gen Pharmacol 1998; 31: 349-356.
20. Ben-Jebria A, Marthan R, Rossetti M, Savineau JP, Ultman JS. Effect of in vitro exposure to acrolein on carbachol responses in rat trachealis muscle. Respir Physiol 1993; 93: 111-123.

21. Ouedraogo N, Roux E, Forestier F, Rossetti M, Savineau JP, Marthan R. Effects of intravenous anesthetics on normal and passively sensitized human isolated airway smooth muscle. Anesthesiology 1998; 88: 317-326.

22. Guibert C, Marthan R, Savineau JP. Oscillatory $\mathrm{Cl}^{-}$ current induced by angiotensin II in rat pulmonary arterial myocytes: $\mathrm{Ca}^{2+}$ dependence and physiological implication. Cell Calcium 1997; 21: 421-429.

23. Meddings JB, Scott RB, Fick GH. Analysis and comparison of sigmoidal curves: application to dose-response data. Am J Physiol 1989; 257: G982-G989.

24. Barlow R, Blake JF. Hill coefficient and the logistic equation. Trends Pharmacol Sci 1989; 10: 440-441.

25. Zhang L. Adaptation of pharmacomechanical coupling of vascular smooth muscle to chronic hypoxia. Comp Biochem Physiol A (Mol Integr Physiol) 1998; 119: 661667.

26. Marriott JF, Marshall JM. Differential effects of hypoxia upon contractions evoked by potassium and noradrenaline in rabbit arteries in vitro. J Physiol (Lond) 1990; 422: 1-13.

27. Zhou L, Zhao Y, Nijland R, Zhang L, Longo LD. Ins(1,4,5)P3 receptors in cerebral arteries: changes with development and high-altitude hypoxia. Am J Physiol 1997; 272: R1954-R1959.

28. Savineau JP, Marthan R. Modulation of the calcium sensitivity of the smooth muscle contractile apparatus: molecular mechanisms, pharmacological and pathophysiological implications. Fundam Clin Pharmacol 1997; 11: 289-299. 